\title{
Sentenced to Death, Saved by Meigs
}

\author{
Minier Rodriguez Luis Enoc ${ }^{1 *}$, Hércules Carbajal Mayra Yolanda ${ }^{1}$ and Crespo Moreno Ricardo ${ }^{2}$ \\ ${ }^{1}$ MIR4 Medicina familiary comunitaria, Health Center Santa María Benquerencia, Toledo \\ ${ }^{2}$ Servicio de Medicina Interna Hospital Virgen de la Salud, Toledo
}

Submission: December 29, 2016 ; Published: January 26, 2017

*Corresponding author: Luis E Minier Rodriguez, MIR4 Medicina familiary comunitaria, Health Center Santa María Benquerencia, España, Calle Río Guadarrama, Toledo, Email: Iminier@sescam.jccm.es

\begin{abstract}
Background: Meigs syndrome is an entity characterized by the association of pleural effusion, ascites and a benign ovarian tumor, with spontaneous resolution of the tumor after resection of the tumor.

Case report: We report a case of a 54-year-old woman with a known history of supraventricular paroxysmal tachycardia, who comes to the emergency department due to dyspnea, lower limb edema and abdominal distension of three days. Presenting the physical examination: Right basal hypofonesis, right lower quadrant mass of the abdomen and lower extremity edema. On the radiograph, there is a right spill. In abdominal CT, adnexal mass compatible with ovarian neoplasia is observed. In analytical, the CA-125 tumor marker elevates $151 \mathrm{U} / \mathrm{ml}$. Before the suspicion of ovarian neoplasia the tumor is resected, whose pathological anatomy is reported as a right adnexal torsed fibroma, being compatible with a Meigs Syndrome. Subsequently the patient presents a progressive recovery of their functional situation and normalizes the clinical parameters.
\end{abstract}

Conclusion: Despite being a rare disease, Meigs syndrome is an entity to be taken into account in a suggestive case of ovarian neoplasia that is accompanied by pleural effusion and ascites, especially since it is an entity with curative treatment despite of its clinical presentation suggestive of malignancy.

Keywords: Meigs syndrome; Ovarian tumor; Pleural effusion; Ascites

\section{Introduction}

Meigs syndrome is a rare nosological entity. The clinical picture is characterized by the association between a benign ovarian tumor (fibroma, thecoma, Brenner's tumor), pleural effusion and ascites. Treatment consists of surgical resection of the pelvic mass, after which spontaneous resolution of pleural and peritoneal effusion occurs, 2 . Contrary to the real nature of this pathology, its highly suggestive clinical presentation of disseminated malignancy does not necessarily mean advanced malignancy and does not exclude curative treatment [1].

If the same signs are associated with malignant tumors, the disease is called pseudo-Meigs syndrome.

\section{Case Report}

54-year-old female with a known history of stroke with left residual hemiplegia and supraventricular paroxysmal tachycardia, who comes to the emergency room due to progressive increase in dyspnea until minimal exertion, lower extremity edema and abdominal distension of three days.
Physical examination shows hypophonesis in the right lung base, increased consistency at the lower right quadrant of the abdomen and edema with fovea in both lower limbs. The radiograph shows: Increased cardiothoracic index and right pleural effusion with passive atelectasis of the right and middle lobes [2-5] (Figure 1\&2).



Figure 1: Increased cardiothoracic index and right pleural effusion with passive atelectasis of the right and middle lobes. 




It enters and initiates treatment with diuretics with good initial response, improving the edema of lower limbs, although the pleural effusion persists. Together with the discrete alteration of acute phase reactants, it is possible to suspect a different etiology from heart failure. Evacuation thoracentesis was performed with $4000 \mathrm{cc}$ of exudate-type pleural fluid, with subsequent relapse in the left hemitorax.

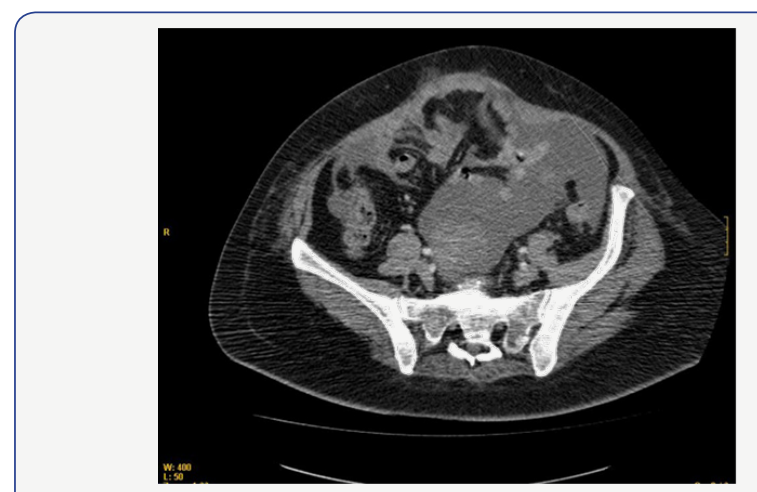

Figure 3: ovarian dependent mass suggestive of ovarian neoplasm and loculated ascites.

Thoraco-abdominal CT scan showing right pleural effusion, ovarian dependent mass suggestive of ovarian neoplasm and loculated ascites (Figure 3). The analytical highlights: CA-125: $151 \mathrm{U} / \mathrm{ml}$ (normal 0-35). Glucose* $100 \mathrm{mg}$ / dL (normal 60-100), Proteins** 3.80 g / dL (normal 1 -2), LDH 328 mU / mL, Amylase (pH 7.56, Leukocytes 409 / mm3) 32 mU / mL, Neutrophils 4\%, Lymphocytes 86\%, Monocytes 8\%, Eosinophils 2\%), abundant cellularity, macrophages with images of phagocytosis inside, lymphocyte predominance, mesothelial cells, and cytology negative for malignant cells. Peritoneal fluid puncture (FNA): Lymphocytic predominance. Mesothelial cells and negative cytology are seen for malignant cells.

At the time of admission, the patient had a fever that was initially suspected to be tumoral, but empirical antibiotic therapy with Piperazilina-Tazobactam was decided, and subsequently changed to Imipenem plus Vancomycin, before the clinic of bacteremia with a significant increase of acute phase reactants, gradually disappearing despite if no causal agent has been isolated in the different blood cultures. Needs transfusion of hemoconcentrates by progressive anemization without data of acute digestive bleeding, until later stabilization.

\section{Evolution}

Before the suspicion of ovarian neoplasia tumor resection is decided, reporting the pathological anatomy as a right adnexal torsed fibroma, the clinical picture being compatible with a Meigs Syndrome [6].

Subsequently the patient presents a progressive recovery of their functional situation, with improvement of the inflammatory markers, normalizing platelet numbers and with the rest of the parameters within the normality.

\section{Discussion}

Meigs syndrome is a rare entity that can lead to diagnostic confusion with much more common entities in our clinical practice, both in its initial assessment in the anamnesis and physical examination, as well as in the complementary tests.

In this particular patient, with a personal history, and clinical presentation consisting of edema and dyspnea, it was reasonable to think that we were probably in the presence of heart failure in a probable relation with supraventricular tachycardia episode. Subsequent to the extension of the study, even with the complementary tests that included CATs and tumor markers, the initial presumption was directed towards advanced stage ovarian neoplasia, suspecting that it was not ruled out until the result of the pathological anatomy [7].

\section{Conclusion}

Despite being a rare disease, Meigs syndrome is an entity to be taken into account in a suggestive case of ovarian neoplasia that is accompanied by pleural effusion and ascites, especially since it is an entity that has curative treatment despite its clinical presentation suggestive of malignancy.

\section{References}

1. P Lopez Sánchez, J Laforga, P Torregrosa, JL Garcia Escobar, J Rius Jordà Meig's (2012) syndrome: presentation of two cases. 45(9) septiembre, Nowak.

2. Krenke R, Maskey Warzechowska M, Korczynski P, Zielinska Krawczyk M, Klimiuk J (2015) Pleural Effusion in Meigs' Syndrome-Transudate or Exudate?: Systematic Review of the Literature. Medicine Baltimore 94(49): e2114.

3. EM Losa, M Villar, A Pascual, T Gómez, G Gónzalez de (2006) Merlo Síndrome de Meigs y seudo-Meigs. Clinica e investigación en ginecología y obstetricia 33(1).

4. M Podciechowski L, Krawczyk T, Wilczynski J (2009) Meigs' syndrome. A case report and review of the literature. Neuro Endocrinol Lett 30: 192.

5. (2001) European Journal of Obstetrics \& Gynecology and Reproductive Biology. 1: 115-120. 
6. Sánchez-Torres DA, Díaz-Murillo R, Kazlauskas S, de Santiago J Zapardiel I (2016) Meigs' syndrome caused by bilateral ovarian fibroma mimicking ovarian cancer. Ginecol Obstet Mex. 2016 84(2): 122-125.

This work is licensed under Creative Commons Attribution 4.0 License

DOI:10.19080/JGWH.2017.02.555580
7. Abad A, Cazorla E, Ruiz F, Aznar I, Asins E, et al. (1999) Meigs' syndrome with elevated CA125: case report and review of the literature. Eur J Obstet Gynecol Reprod Biol 82(1): 97-99.

\section{Your next submission with Juniper Publishers will reach you the below assets}

- Quality Editorial service

- Swift Peer Review

- Reprints availability

- E-prints Service

- Manuscript Podcast for convenient understanding

- Global attainment for your research

- Manuscript accessibility in different formats

( Pdf, E-pub, Full Text, Audio)

- Unceasing customer service

Track the below URL for one-step submission

https://juniperpublishers.com/online-submission.php 